\title{
UPAYA DOSEN KEWIRAUSAHAAN SEBAGAI FAKTOR DETERMINATIF DALAM MENUMBUHKAN MOTIVASI WIRAUSAHA MAHASISWA IKIP SILIWANGI
}

\author{
Sugita1 ${ }^{1}$ Ansori² \\ 1,2 IKIP Siliwangi
}

${ }^{1}$ kangsugita@gmail.com

\begin{abstract}
ABSTRAK
Dosen adalah pendidik profesional dan ilmuwan dengan tugas utama mentransformasikan, mengembangkan, menyebarluaskan ilmu pengetahuan, teknologi, dan seni melalui pendidikan, penelitian, dan pengabdian kepada masyarakat. Kemampuan dosen kewirausahaan sebagai faktor determinatif dalam menumbuhkan motivasi wirausaha mahasiswa harus memiliki kompetensi kewirausahaan dan kepribadian yang baik. Upaya untuk meningkatkan minat dan motivasi mahasiswa yakni dapat dilakukan dengan cara pembuatan pusat studi kewirausahaan kampus seperti koperasi mahasiswa, koperasi mahasiswa ini diharapkan akan banyak kegiatan yang dapat dilaksanakan seperti : seminar, pelatihan, loka karya, praktek usaha, kerjasama usaha, dll. Kemudian dalam hal peningkatan Dosen sebagai tenaga pendidik ini dapat dilakukan dengan melalui berbagai cara, diantaranya sebagai berikut : 1) Program pelatihan kewirausahaan untuk tenaga pendidik, 2) Program seminar, workshop, lokakarya kewirausahaan. 3) Program pemagangan dosen di dunia usaha, 4) Program sarasehan dengan mitra usaha, 5) Program pembinaan dan pendampingan dosen baru.
\end{abstract}

Kata kunci : Dosen, Kewirausahaan, Motivasi Wirausaha

\section{A. PENDAHULUAN}

Dalam Undang -Undang Guru dan Dosen UU RI Nomor 14 Tahun 2005 Dosen adalah pendidik profesional dan ilmuwan dengan tugas utama men-transformasikan, mengembangkan, menyebarluaskan ilmu pengetahuan, teknologi, dan seni melalui pendidikan, penelitian, dan pengabdian kepada masyarakat. Kedudukan dosen sebagai tenaga profesional bertujuan untuk melaksanakan sistem pendidikan nasional dan mewujudkan tujuan pendidikan nasional, yaitu berkembangnya potensi peserta didik agar menjadi manusia yang beriman dan bertakwa kepada Tuhan Yang Maha Esa, berakhlak mulia, sehat, berilmu, cakap, kreatif, mandiri, serta menjadi warga negara yang demokratis dan bertanggung jawab. Untuk menjamin perluasan dan pemerataan akses, peningkatan mutu dan relevansi, serta tata pemerintahan yang baik dan akuntabilitas pendidikan yang mampu menghadapi tantangan sesuai dengan tuntutan perubahan kehidupan lokal, nasional, dan global perlu dilakukan pemberdayaan dan peningkatan mutu guru dan dosen secara terencana, terarah, dan berkesinambungan; bahwa guru dan dosen mem-punyai fungsi, peran, dan kedudukan yang sangat strategis dalam pembangunan nasional dalam bidang pendidikan.

IKIP Siliwangi yang menjadi salah satu lembaga pendidikan tinggi di Indonesia yang berkiprah dalam bidang pendidikan sebagai lembaga penghasil tenaga pendidik yang 
mengutamakan mutu, relevan dengan kebutuhan masyarakat, dan tanggap serta peka terhadap arus globalisasi dan perkembangan IPTEK serta menghasilkan tenaga pendidik yang berjiwa entrepreneur. Untuk menghasilkan tenaga pendidik yang berjiwa entrepreneur. Peran dosen sangat berpengaruh terhadap keberhasilan suatu kegiatan belajar mengajar, sehingga mahasiswa dapat memetik hasil dari apa yang di sampaikan oleh dosen baik itu dari segi aspek kognitif, apektif maupun psikomotor. Salah satu upaya untuk menghasilkan tenaga pendidik yang berjiwa entrepreneur, di kampus IKIP Siliwangi telah menerapkan mata kuliah kewirausahaan di semua program studi yang awalnya hanya ada di program studi pendidikan luar sekolah yang sekarang menjadi program studi pendidikan masyarakat. Dosen kewirausahaan sebagai faktor determinatif dalam menumbuhkan motivasi wirausaha mahasiswa harus bisa menumbuhkan semangat motivasi berwirausaha mahasiswa, bukan hanya memberikan materi kewirausahaan saja namun dosen kewirausahaan juga harus mampu membimbing mahasiswa untuk bisa praktek berwirausaha di lapangan. Di harapkan ketika lulus nanti mahasiswa tidak hanya mengandalkan ijazah saja untuk dapat bekerja tetapi memiliki kemampuan untuk berwirausaha sehingga mampu membuka lapangan pekerjaan mengingat semakin sempitnya lapangan pekerjaan dan semakin tingginya angka pengangguran. Oleh karena itu mahasiswa sebagai agen of change harus terdepan dalam meningkatkan perekeonomian bangsa, berwirausaha sedini mungkin agar mampu bersaing dengan pelaku wirausaha dikemudian hari. Bagaimana mahasiswa bukan hanya tumbuh motivasi wirausaha dalam dirinya tetapi tumbuh menjadi wirausaha sejati.

\section{B. KAJIAN TEORI}

\section{Dosen}

Menurut Undang-undang RI No. 14 tahun 2005, Dosen adalah pendidik profesional dan ilmuwan dengan tugas utama mentransformasikan, mengembangkan, dan menyebarluaskan ilmu pengetahuan, teknologi, dan seni melalui pendidikan, penelitian, dan pengabdian kepada masyarakat.

\section{Faktor Determinatif}

Menurut Kamus Besar Bahasa Indonesia (KBBI) determinatif bersifat menentukan : untuk berkomunikasi, bahasa merupakan unsur yang determinatif dalam kehidupan manusia.

\section{Kewirausahaan}

Menurut Instruksi Presiden RI No. 4 Tahun 1995 : “ Kewirausahaan adalah semangat, sikap, perilaku, dan kemampuan seseorang dalam menangani usaha dan atau kegiatan yang mengarah pada upaya mencari, menciptakan, menerapkan cara kerja, teknologi, dan produk baru dengan meningkatkan efisiensi dalam rangka memberikan pelayanan yang lebih baik dan atau memperoleh keuntungan yang lebih besar".

Menurut Indriyatni (2013:54) dalam (Christianingrum, 2017), berwirausaha adalah upaya-upaya yang berkaitan dengan penciptaan kegiatan usaha atau aktifitas bisnis atas dasar kemauan sendiri, dan/atau mendirikan usaha/bisnis dengan kemauan dan kemampuan sendiri. Pengertian wirausaha dan kewirausahaan, dalam lampiran Keputusan Menteri Koperasi dan Pembinaan Pengusaha Kecil Nomor 961/KEP/MX/1995, dicantumkan bahwa : 
1. Wirausaha adalah orang yang mempunyai semangat, sikap, perilaku dan kemampuan kewirausahaan.

2. Kewirausahaan adalah semangat, sikap, perilaku dan kemampuan seseorang dalam menangani usaha atau kegiatan yang mengarah pada upaya mencari, menciptakan serta menerapkan cara kerja teknologi dan produk baru dengan menciptakan serta menerapkan cara kerja teknologi dan produk baru dengan meningkatkan efisiensi dalam rangka memberikan pelayanan yang lebih baik dan atau memperoleh keuntungan yang lebih besar.

Kewirausahaa adalah disiplin ilmu yang mempelajari tentang nilai, kemampuan, dari perilaku seseorang dalam menghadapi tantangan hidup untuk memperoleh peluang dengan berbagai risiko yang mungkin di hadapinya.

Pada awalnya, sejak tahun 1975 istilah enterpreneur diidentikan ke dalam bahasa Indonesia menjadi wiraswasta. Istilah "wiraswasta" berasal dari bahasa

Sansekerta. Wiraswasta terdiri atas tiga suku kata : wira, swa dan sta. Wira berarti manusia unggul,teladan, tangguh, berbudi luhur, berpikiran maju, berjiwa besar, berani, pahlawan, pionir, pendekar kemajuan dan memiliki keagungan watak. Swa berarti sendiri, dan sta berarti sendiri. Dengan demikian wiraswasta dapat diartikan manusia unggul yang mampu hidup diatas kekuataan sendiri. Lengkapnya manusia unggul yang mampu hidup diatas kekuatan sendiri, bahkan mampu menciptkan lapangan kerja bagi orang lain.

Namun, sejak awal tahun 1990-an mulai muncul penggunaan istilah wirausaha. Dalam bahasa asingnya kedua istilah ( wiraswasta dan wirausaha ) tersebut berasal dari istilah yang sama, yaitu entrepreneur. Istilah wirausaha terdiri atas dua suku kata : wira dan usaha. Usaha berarti kegiatan dengan mengerahkan tenaga, pikiran, atau badan ( institusi ) untuk mencapai suatu maksud, pekerjaan (perbuatan, prakarsa, ikhtiar, daya upaya ) untuk mencapai suatu maksud, kegiatan di bidang perdagangan ( dengan mencari untung ), perdagangan, perusahaan (Kamus Besar Bahasa Indonesia ).

Oleh karena itu, wirausaha dapat diartikan sebagai manusia unggul yang mampu melakukan kegiatan/ pekerjaan untuk mencapai suatu maksud yang dalam bidang perdagangan perusahaan dengan maksud mencari untung, bahkan mampu membantu terutama dalam menciptakan lapangan kerja bagi orang lain. Meskipun dalam kehidupan sehari-hari, kata wiraswasta atau wirausaha sering dipergunakan seseorang sebagai salah satu jenis pekerjaan nonpegawai negeri dan nonpegawai swasta atau sejenisnya, tetapi atas usaha sendiri. Jiwa wiraswasta atau wirausaha biasanya tumbuh dan berkembang dengan baik di lapangan atau dunia usaha terutama di daerah perkotaan (Astim R, 2013).

\section{Motivasi Wirausaha}

Produktivitas suatu pekerjaan sangat tergantung kepada kemauan para pekerja untuk bekerja lebih giat. Oleh karena itu agar giat dalam melakukan sebuah pekerjaan, maka perlu di beri motivasi dengan berbagai cara. Pada umumnya manusia bertingkah laku secara sadar, artinya didorong oleh keinginan untuk mencapai tujuan tertentu. Disinilah letaknya peran penting motivasi. 
Motivasi adalah kemauan untuk berbuat sesuatu, sedangkan motif adalah kebutuhan, keinginan, dorongan atau impuls. Motivasi seseorang tergantung kekuatan motifnya. Motif dengan kekuatan yang sangat besarlah yang akan menentukan perilaku seseorang. Motif yang kuat ini sering kali berkurang apabila telah mencapai kepuasan ataupun karena menemui kegagalan (Alma, 2013).

Teori motivasi yang sangat populer ialah teori hirarki kebutuhan yang dikemukakan oleh Abraham Maslow. Maslow berpendapat bahwa hirarki kebutuhan manusia dapat dipakai untuk melukiskan dan meramalkan motivasinya. Teori tentang motivasi didasarkan oleh dua asumsi. Pertama, kebutuhan seseorang tergantung dari apa yang telah dipunyainya, dan kedua, kebutuhan merupakan hirarki dilihat dari pentingnya. Menurut maslow ada lima kategori kebutuhan manusia, yaitu : physiological needs, safety ( security ). Social ( affiliation ), esteem ( recognition ), dan self actualization.

Dari pengertian diatas dapat disimpulkan bshwa motivasi wirausaha adalah kemauan sesorang untuk melakukan kegiatan kewirausahaan berdasarkan dorongan dari individunya sendiri ataupun dari luar.

\section{PEMBAHASAN}

Kewirausahaan adalah proses dinamik untuk menciptakan tambahan kemakmuran (Buchari Alma, 2011:33). Istilah kewirausahaan berasal dari terjemahan "Entrepreneurship", Menurut Thomas W. Zimmerer, Kewirausahaan merupakan gabungan dari kreativitas, inovasi dan keberanian menghadapi resiko yang dilakukan dengan cara kerja keras untuk membentuk usaha baru.

Kata "Wirausaha" merupakan terjemahan dari istilah bahasa inggris entrepreneur, yang artinya adalah orang-orang yang mempunyai kemampuan untuk melihat dan menilai kesempatan peluang bisnis.J. B. Say menggambarkan pengusaha sebagai orang yang mampu memindahkan sumber-sumber ekonomi dari tingkat produktivitas rendah ke tingkat produktivitas tinggi karena mampu menghasilkan produk yang lebih banyak. Kewirausahaan berasal dari kata wira dan usaha.Menurut dari segi etimologi (asal usul kata).Wira, artinya pejuang, pahlawan, manusia unggul, teladan, gagah berani, berjiwa besar, dan berwatak agung.Usaha, artinya perbuatan amal, bekerja, berbuat sesuatu.Jadi, wirausaha adalah pejuang atau pahlawan yang berbuat sesuatu. Wirausaha dapat mengumpulkan sumber daya yang di butuhkan guna mengambil keuntungan dari padanya, dan mengambil tindakan yang tepat guna untuk memastikan keberhasilan usahanya. Wirausaha ini bukan faktor keturunan atau bakat, tetapi sesuatu yang dapat dipelajari dan dikembangkan.

Menurut (Ansori, 2014), seorang entrepreneur atau wirausahawan dalam menjalankan sesuatu selalu dengan pertimbangan yang matang dan tidak asal-asalan, itulah yang membedakan entrepreneur sejati dengan entrepreneur asal jadi. Sehingga dapat diketahui ciri-ciri seorang entrepreneur sejati ialah ia memiliki jiwa wirausaha.

Adapun ciri-cirinya adalah sebagai berikut: 1 . Percaya diri, kepercayaan diri merupakan suatu paduan sikap dan keyakinan seseorang dalam menghadapi tugas atau pekerjaan. 
Dalam praktik, sikap dan kepercayaan ini merupakan sikap dan keyakinan untuk memulai, melakukan dan menyelesaikan suatu tugas atau pekerjaan yang dihadapi.Oleh sebab itu kepercayaan diri memiliki nilai keyakinan, optimis, individualitas, dan ketidaktergantungan. Seseorang yang memiliki kepercayaan diri cenderung memiliki keyakinan akan kemampuannya untuk mencapai keberhasilan. 2. Berorientasi pada tugas dan hasil Seseorang yang selalu mengutamakan tugas dan hasil, adalah orang yang selalu mengutamakan nilai-nilai motif berprestasi, berorientasi pada laba, ketekunan dan ketabahan, tekad kerja keras, mempunyai dorongan kuat, energik, dan berinisiatif.Berinisiatif artinya selalu ingin mencari dan memulai.Untuk memulai diperlukan niat dan tekad yang kuat, serta karsa yang besar. Sekali sukses atau berprestasi, makasukses berikutnya akan menyusul, sehingga usahanya semakin maju dan semakin berkembang.

Dalam pendapat (Saragih, 2017) kewirausahaan merupakan suatu proses dinamis untuk menciptakan nilai tambah atas barang dan jasa serta kemakmuran. Peter F.Drucker (1994) mendefinisikan kewirausahaan sebagai kemampuan untuk menciptakan sesuatu yang baru dan berbeda. Thomas W. Zimmerer (1996;51) mengungkapkan bahwa kewirausahaan merupakan proses penerapan kreativitas dan inovasi untuk memecahkan masalah dan mencari peluang yang dihadapi setiap orang dalam kehidupan sehari- hari. Inti dari kewirausahaan adalah kemampuan untuk menciptakan sesuatu yang baru dan berbeda melalui pemikiran kreatif dan tindakan inovatif demi terciptanya peluang. Kemudian Thomas W. Zimmerer et al (2005) dalam (Saragih, 2017) merumuskan manfaat berwirauaha sebagai berikut:

1. Memberi peluang dan kebebasan untuk mengendalikan nasib sendiri.

2. Memberi peluang melakukan perubahan : Pebisnis menemukan cara untuk mengombinasikan wujudkepedulian mereka terhadap berbagai masalah ekonomi dan social dengan harapan akan menjalani kehidupan yang lebih baik

3. Memberi peluang untuk mencapai potensi diri sepenuhnya : Memilikiusaha sendiri

memberikankekuasaan,kebangkitan spiritual dan membuat wirausaha mampu mengikuti minat atau hobinya sendiri.

4. Memiliki peluang untuk meraih keuntungan seoptimal mungkin

5. Memiliki peluang untuk berperan aktif dalam masyarakat dan mendapatkan pengakuan atas usahanya

6. Memilikipeluanguntuk melakukan sesuatu yang disukai dan menumbuhkan rasa senang dalam mengerjakannya

Percaya diri merupakan modal awal untuk menjadi seorang wirausaha, keyakinan terhadap produk yang di hasilkan menumbuhkan optimisme yang tinggi sehingga apa yang dijalankan tanpa ada rasa ragu sedikitpun. Motivasi dalam diri seseorang akan tumbuh ketika ada dorongan baik itu dari eksternal maupun dari internal, sehingga keinginan mencapai suatu hal membuat seseorang bergerak untuk mewujudkannya. Dosen kewirausahaan salah satu faktor eksternal mahasiswa untuk berani berwirausaha,oleh karena itu dosen kewirausahaan harus ekstra dalam menumbuhkan motivasi berwirausaha mahasiswa.

Sebagaimana dalam Undang -Undang Guru dan Dosen UU RI Nomor 14 Tahun 2005 Dosen adalah pendidik profesional dan ilmuwan dengan tugas utama men- 
transformasikan, mengembangkan, menyebarluaskan ilmu pengetahuan, teknologi, dan seni melalui pendidikan, penelitian, dan pengabdian kepada masyarakat. Mentransformasikan ilmu pengetahuan agar dapat di terima oleh mahasiswa bukan perkara mudah apalagi perihal tentang kewirausahaan, bukan hanya ilmu saja yang dapat tersampaikan melainkan dosen harus bisa membimbing sehingga mahasiswa dapat mempraktekan kewirausahaan dilapangan. Melihat kedudukan dosen sebagai tenaga profesional bertujuan untuk melaksanakan sistem pendidikan nasional dan mewujudkan tujuan pendidikan nasional, yaitu berkembangnya potensi peserta didik agar menjadi manusia yang beriman dan bertakwa kepada Tuhan Yang Maha Esa, berakhlak mulia, sehat, berilmu, cakap, kreatif, mandiri, serta menjadi warga negara yang demokratis dan bertanggung jawab. Dalam melaksanakan sistem pendidikan nasional dan mewujudkan pendidikan nasional dosen harus memiliki kemampuan yang profesional dalam bidangnya. Keberhasilan seorang dosen dalam mentransformasikan ilmu terhadap mahasiswa bisa kita lihat melalui prestasi belajar mahasiswa, ketika dosen kewirausahaan mampu menumbuhkan motivasi wirausaha mahasiswanya kemudian dapat mendorong mahasiswa untuk berwirausaha, itu merupakan sebuah prestasi belajar.

Sebagaimana menurut (Mediawati, 2010) Guru (baca: dosen) merupakan salah satu faktor eksternal yang mempengaruhi prestasi belajar. Guru merupakan komponen yang memiliki peranan strategis dalam pelaksanaan pembelajaran. Guru memiliki peranan kunci dalam setiap upaya peningkatan mutu, relevansi, dan efisiensi pendidikan. Di tangan pengajar mutu pendidikan dapat diupayakan ke arah yang lebih baik. Hal tersebut memaksa guru agar mampu dipersiapkan secara optimal kompetensinya, karena bagaimanapun kompetensi guru mencerminkan kinerja guru atau kemampuan guru dalam mengajar di kelas sehingga dapat dipastikan semakin baik kompetensi yang dimiliki guru, maka besar kemungkinan prestasi belajar siswa pun akan akan meningkat pula. Wijaya dan Rusyan (1994:1) mengemukakan bahwa guru merupakan faktor yang sangat dominan dan paling penting dalam pendidikan formal pada umumnya karena bagi siswa guru sering dijadikan tokoh teladan, bahkan menjadi tokoh identifikasi diri. Oleh karena itu, guru seyogyanya memiliki perilaku dan kemampuan yang memadai untuk menggembangkan siswanya secara utuh. Untuk melaksanakan tugasnya secara baik sesuai dengan profesi yang dimilikinya, guru perlu menguasai berbagai hal sebagai kompetensi yang dimilikinya. Termasuk internalisasi nilai-nilai kependidikan yang akan mendorongnya menjadi model bagi peserta didik (Fitriana \& Mulyono, 2019).

Kemudian perguruan tinggi harus mempersiapkan tenaga pendidik atau Dosen yang mampu melakukan hal-hal sebagai berikut, yaitu:

1. Memberikan paradigma baru tentang pentingnya kewirausahaan.

2. Menginspirasi dan memotivasi mahasiswa menjadi SDM yang mandiri.

3. Merubah atau mengarahkan pola pikir mahasiswa menjadi seorang yang berjiwa wirausaha.

4. Memberikan contoh karya nyata kewirausahaan dan menyuguhkan cerita sukses.

5. Menghasilkan mahasiswa atau alumni menjadi seorang wirausaha sukses.

Program peningkatan Dosen sebagai tenaga pendidik ini dapat dilakukan dengan melalui berbagai cara, diantaranya sebagai berikut: 
1. Program pelatihan kewirausahaan untuk tenaga pendidik,

2. Program seminar, workshop, lokakarya kewirausahaan.

3. Program pemagangan dosen di dunia usaha,

4. Program sarasehan dengan mitra usaha,

5. Program pembinaan dan pendampingan dosen baru.

Dengan program tersebut, tentunya setiap dosen tidak hanya sekedar mengajar kewirausahaan saja, tetapi mampu mewujudkan dan merealisasikan apa yang telah diberikan kepada mahasiswa pada saat mengajar.

Selain kompetensi dosen sebagai faktor dalam menumbuhkan motivasi berwirausaha mahasiswa, kepribadian seorang dosen pun menjadi hal yang sangat berperan. Penilaian baik atau buruk seseorang bisa tercermin dari kepribadiannya begitupun seorang dosen dimata mahasiswanya. Kata kepribadian berasal dari Personality ( bahasa inggris ) yang berasal dari kata Persona ( bahasa latin ) yang berarti kedok atau topeng. Menutut Allport (Rosalind, 2012), kepribadian adalah suatu organisasi ( psikosifik ) yang dinamis dalam diri individu, yang menentukan tingkah laku yang khas ( unik ) dari orang tersebut. Kepribadian merupakan sesuatu yang berubah. Meskipun begitu, kepribadian merupakan karakteristik yang relatif stabil. Pandangan orang secara umum mengenai kepribadian sebagai sesuatu yang ajek, konsisten, dan tidak berubah, tidak sepenuhnya salah. Di samping itu, kepribadian sering diidentikan dengan ciri - ciri yang menonjol pada diri individu. Kompetensi dosen yang baik perlu di tunjang dengan kepribadian dosen yang baik juga, bukan hanya sekedar harapan mahasiswa namun suatu keharusan bagi mahasiswa. Ilmu kewirausahaan bisa dipelajari semua orang namun tidak semua orang dapat mempraktekan kewirarausahaan itu sendiri, mahasiswa sebagai aggent of change harus bisa menjadi yang terdepan dalam dunia wirausaha. Peran dosen kewirausahaan sebagai faktor internal harus memiliki kompetensi dan kepribadian yang baik, dua hal tersebut harus dimiliki dalam menumbuhkan motivasi wirausaha mahasiswa. Pendekatan kewirausahaan harus menekankan pada upaya membangun kompetensi dan pengalaman secara bersamaan, terutama untuk mengembangkan kapasitas mahasiswa dan masyarakat, yang secara khusus adalah kaum perempuan untuk peningkatan kualitas kehidupannya (Karwati, Ansori \& Mulyono, 2018).

Menurut Febrianto (Febriyanto, 2015) di negara kita Indonesia, usaha dalam menanamkan jiwa dan semangat kewirausahaan bagi mahasiswa di perguruan tinggi terus digalakan dan ditingkatkan, tentunya dengan berbagai metode dan strategi yang membuat mahasiswa tertarik untuk berwirausaha.Bahkan pada tingkat pemerintah melalui Kementrian Koordinator Perekonomian telah memberikan peraturan kepada seluruh lembaga pendidikan yang ada di Indonesia, dari pendidikan dasar sampai pendidikan tinggi diwajibkan untuk memberikan mata pelajaran atau mata kuliah Kewirausahaan tersebut. Ada beberapa usaha atau teknik yang perlu diterapkan dalam meningkatkan minat dan kegiatan kewirausahaan bagi para peserta didik, yaitu:

1. Pembentukan Pusat studi kewirusahaan Kampus, melalui media pembentukan pusat kewirausahaan kampus tersebut, akan banyak kegiatan yang dapat dilaksanakan seperti: Seminar, Pelatihan, Loka karya, Praktek usaha, kerjasama usaha, dll. 
2. Menganggap penting kewirausahaan dikampus dan menjadikan mata kuliah kewirausahaan sebagai hal yang harus diberikan kepada mahasiswa, materi kewirausahaan tidak sebatas formalitas, sehingga harus di design materi dan metode dalam pembelajarannya.

3. Memaksimalkan dalam memanfaatkan Program kewirausahaan yang digagas oleh lembaga pemerintah, seperti: pendidikan tinggi (Dikti) melalui Direktur Kelembagaan Ditjen Dikti dan disampaikan kepada para PTS melalui Kopertis.

Dari beberapa strategi tersebut, jika diimplementasikan oleh perguruan tinggi dengan serius dan sungguh-sungguh maka dapat dimungkinkan akan banyak muncul wirausahawan sukses yang berasal dari tenaga muda terdidik di negeri ini, yang dapat berperan dalam meningkatkan ekonomi kerakyatan dan pergerakan aktivitas ekonomi lokal. Peran perekonomian lokal dalam hal ini sistem ekologi merupakan modal sosial dalam pembangunan Indonesia yang lebih baik di masa yang akan datang (Mulyono, 2018).

\section{KESIMPULAN}

Dosen sebagai faktor determinatif dalam menumbuhkan motivasi berwirausaha dikalangan mahasiswa harus memiliki kompetensi yang baik dan kepribadian yang baik. Peningkatan kompetensi Dosen sebagai tenaga pendidik ini dapat dilakukan dengan melalui berbagai cara, diantaranya sebagai berikut:

1. Program pelatihan kewirausahaan untuk tenaga pendidik,

2. Program seminar, workshop, lokakarya kewirausahaan.

3. Program pemagangan dosen di dunia usaha,

4. Program sarasehan dengan mitra usaha,

5. Program pembinaan dan pendampingan dosen baru.

Kemudian ada beberapa usaha atau teknik yang perlu diterapkan dalam meningkatkan minat dan kegiatan kewirausahaan bagi para peserta didik, yaitu:

1. Pembentukan Pusat studi kewirusahaan Kampus, seperti: Melalui media pembentukan pusat kewirausahaan kampus tersebut, akan banyak kegiatan yang dapat dilaksanakan seperti: Seminar, Pelatihan, Loka karya, Praktek usaha, kerjasama usaha, dll.

2. Menganggap penting kewirausahaan dikampus dan menjadikan mata kuliah kewirausahaan sebagai hal yang harus diberikan kepada mahasiswa, materi kewirausahaan tidak sebatas formalitas, sehingga harus di design materi dan metode dalam pembelajarannya.

3. Memaksimalkan dalam memanfaatkan Program kewirausahaan yang digagas oleh lembaga pemerintah, seperti: pendidikan tinggi (Dikti) melalui Direktur Kelembagaan Ditjen Dikti dan disampaikan kepada para PTS melalui Kopertis.

\section{E. DAFTAR PUSTAKA}

Alma, B. (2013). Kewiraushaan. Bandung: ALFABETA.

Ansori. (2014). Model Pengembangan Kewirausahaan Santri Melalui Pondok Pesantren Berbasis Budaya Agribisnis Tanaman Palawija. Didaktik, 7. 
Anwas, O. M. (2014). Pemberdayaan masyarakat di era global. Bandung: Alfabet.

Ardiwinata, J. S., \& Mulyono, D. (2018). COMMUNITY EDUCATION IN THE DEVELOPMENT OF THE COMMUNITY. Empowerment, Vol 7 (1), 25-35.

Astim R, A. (2013). Kapita Selekta Kewirausahaan. Bandung: YAPEMDO Bandung.

Bustami, Murniati, \& Harun, C. Z. (2010, November). Manajemen Pendidikan PAUD AlFath Sabang. Jurnal Administrasi Pendidikan Pascasarjana Universitas Syiah Kuala, 1(2), 1-12.

Christianingrum, E. R. (2017). PENGARUH PEMBELAJARAN KEWIRAUSAHAAN. Integrated Journal of Business and Economics (IJBE), 49.

depkop. (2017, 12 6). ratio wirausaha. Dipetik 12 6, 2017, dari www.depkop.go.id.

Fatimah, D. F., \& Romah, N. (2016, November). Pola Pengelolaan Pendidikan Anak Usia Dini di PAUD Ceria Gondangsari Jawa Tengah. Manageria: Jurnal Manajemen Pendidikan Islam, 1(2), 247-273.

Fitriana, W., \& Mulyono, D. (2019). IMPLICATION OF INTERNSHIP III PROGRAMS ON SOCIAL COMPETENCY OF SILIWANGI IKIP PENMAS STUDENTS. P2M STKIP Siliwangi, 6(1), 14-20.

Febriyanto. (2015). STRATEGI PENINGKATAN KEWIRAUSAHAAN BAGI MAHASISWA. Jurnal Bisnis Darmajaya, 108.

Firman. (2010). Kebijakan Perijinan Lahan. Jakarta: Lubuk Agung.

Gunawan, I., \& Benty, D. N. (2017). Manajemen Pendidikan: Suatu Pengantar Praktik. Bandung: Alfabeta.

HIMPAUDI. (2010, Agustus 3). Tugas dan Fungsi HIMPAUDI. Retrieved April 12, 2018, from HIMPAUDI: http://himpaudi.or.id/tujuan-dan-fungsi/

Indrayana. (2013, Juli 22). HIMPAUDI - Tata Kerja. Retrieved Maret 12, 2018, from SCRIBD: https://id.scribd.com/doc/9628179/Himpaudi-Tata-Kerja

Kementerian Pendidikan dan Kebudayaan. (2012). Konsep Dasar Pendidikan Anak Usia Dini. Direktorat Jenderal Pendidikan Anak Usia Dini Non Formal Informal. Semarang: P2PNFI Regional II.

Kintamani, I. (2015). Perkembangan pendidikan tahun 2008/2009-2013/2014. Jakarta : Pusat Data dan Statistik Pendidikan dan Kebudayaaan.

Karwati, L., Ansori, A., \& Mulyono, D. (2018). Women Empowerment to Build Entrepreneurship. Journal of Nonformal Education, 4(2), 169-176.

Mediawati, E. (2010). PENGARUH MOTIVASI BELAJAR MAHASISWA DAN KOMPETENSI DOSEN TERHADAP PRESTASI BELAJAR. JURNAL PENDIDIKAN EKONOMI DINAMIKA PENDIDIKAN, 135. 
Melianysari. (2013, Juni 22). Petunjuk dan Teknis Penyelenggaraan Kelompok Bermain. Retrieved Oktober 5, 2017, from https://id.scribd.com/document/375290668/1-Juknis-Penyelenggaraan-KB-doc

Moleong, L. J. (1996). Metodologi Penelitian Kualitatif. Bandung: Remaja Rosdakarya.

Mulyono, D. (2018). THE STRATEGY OF MANAGERS IN MOVING BUSINESS LEARNING GROUP PROGRAM IN PKBM SRIKANDI CIMAHI CITY. Journal of Educational Experts (JEE), Vol. 1 (1), 41-50.

Nuraeni, L., \& Santana, F. D. (2015). Persepsi, Pola Pengasuhan, Dan Peran Sertakeluarga Pemulung Tentang Pendidikan Anak Usia Dini(Studi Deskriptif Pada Keluarga Pemulung Dikampung Cibatu Desa Cilame Kecamatan Ngamprah Kabupaten Bandung Barat). Jurnal Ilmiah UPT P2M STKIP Siliwangi, 2(2), 160168.

Ridho, R., Markhamah, \& Darsinah. (2015, Agustus). Pengelolalaan Pembelajaran Pendidikan Anak Usia Dini (PAUD) Di KB "CERDAS" Kecamatan Sukorejo Kabupaten Kendal. Penelitian Humaniora, 16(2), 59-69.

Rosalind, S. (2012). 59 KEPRIBADIAN PALING DICARI DAN DISUKAI ORANG DI SELURUH DUNIA. Yogyakarta: Sinar Kejora.

sabir, f. m. (2016). Pengaruh Faktor Motivasi, Komitmen Organisasi dan. Pengaruh Faktor Motivasi, Komitmen Organisasi dan, 40.

Saragih, R. (2017). Membangun Usaha Kreatif, Inovatif dan Bermanfaat melalui Penerapan Kewirausahaan Sosial. Jurnal Kewirausahaan, 27.

Sudjana. (2010). Metode dan Teknik Pembelajaran Partisipatif. Bandung: Falah.

Sugiyono. (2014). Metode Penelitian Kualitatif dan Kuantitatif dan R\&D. Bandung: Alfabeta.

Sulastri. (2017). Manajemen Pembelajaran Berbasis Bilingual Di SMP Muhamadiyah 17 Surabaya. Inspirasi Manajemen Pendidikan, 1(2), 1-7.

Suyadi. (2012). Konsep Dasar PAUD. Bandung: PT. Remaja Rosdakarya.

Suyadi, \& Ulfah, M. (2013). Konsep Dasar PAUD. Bandung: PT. Remaja Rosdakarya.

Tedjawati, J. M. (2011, Januari). Peran HIMPAUDI dalam Pengembangan PAUD. Pendidikan dan Kebudayaan, 17(1), 123-133.

Tilaar, H. (2009). Paradigma Baru Pendidikan Nasional. Jakarta: Rineka Cipta.

Usman, H. (2009). Manajemen: Teori, Praktik, dan Riset Pendidikan. Jakarta: PT. Bumi Aksara.

Widiastuti, N., \& Kartika, P. (2017, Oktober). Penerapan Model Kelompok Usaha Kratif Islami (KUKIS) dalam pemberdayaan perempuan berbasis Pondok pesantren. Journal Empowerment Vol 6, No 2, 6, 4. 
Yuniarsih, T., \& Suwatno. (2011). Manajemen Sumber Daya Manusia. Bandung: Alfabeta.

Zaenab, S. (2015, Maret). Pengembangan Manajemen Pendidikan Anak Usia Dini. Manajemen Pendidikan, 24(5), 383-391.

Ratio Wirausaha. [Online]. Tersedia http://www.depkop.go.id/content/read/ratiowirausaha-indonesia-naik-jadi-31-persen/. Diakses pada tanggal 6 desember 2017 